대한치과재료학회지 42(2) : 107-116, 2015

ISSN:1225-1631 (Print); 2384-3268 (Online)

Available online at http://www.kadm.org

http://dx.doi.org/10.14815/kjdm.2015.42.2.107

\title{
$\alpha-\mathrm{TCP}$ 를 첨가한 글라스 아이오노머 시멘트의 법랑질 탈회저항성
}

\author{
강재경 ${ }^{1}$, 김희경 ${ }^{2}$, 이민영 ${ }^{3}$, 김광만 ${ }^{4)}$, 김경남 ${ }^{4)}$, 김명은 ${ }^{2) *}$
}

신구대학교 치위생과 ${ }^{1)}$, 대원대학교 치위생과 ${ }^{2}$, 영동대학교 치위생학과과 ${ }^{3}$, 연세대학교 치과대학 치과생체재료공학교실 및 연구소

$\langle$ Abstract $\rangle$

\section{Resistance to decalcification of enamel of glass ionomer cement with $\alpha-\mathrm{TCP}$ Jae-Kyoung Kang ${ }^{1)}$, Myung-Eun KIM²), Hee-Kyoung Kim(2), Min-Young Lee ${ }^{3)}$, Kwang-Mahn Kim ${ }^{4)}$, Kyoung-Nan $\mathrm{Kim}^{4}$}

Dep. of Dental Hygiene, Shingu College, Seongnam, Korea ${ }^{1)}$, Dep. of Dental Hygiene, Daewon University College, Chungbuk, Korea ${ }^{2}$

Dep. of Dental Hygiene, Youngdong University, Chungbuk, Korea",

Department and Research Institute of Dental Biomaterials and Bioengineering, College of Dentistry,

Yonsei University, Seoul, Korea ${ }^{4}$

The aim of this study was to evaluate changes in decalcification resistance of glass ionomer containing $\alpha$-TCP. Total forty cavities were prepared form extracted bovine teeth and were divided into four groups of ten each in order to evaluate decalcification resistance. The cavities of each groups were restored with glassionomer cement containing $0 \%(G r o u p 1), 5 \%(G r o u p 2), 15 \%(G r o u p 3)$ and 25 $\%$ (Group4) $\alpha$-TCP. After half of each specimen were treated with varnish, there were immersed in a decalcifying solution for 96 hours at $37^{\circ} \mathrm{C}$. The mineral loss of specimens were measured by fluorescence loss values using a QLF-D. In addition, compressive strength were measured according to ISO 9917-1. According to the results, loss of fluorescence $\triangle \mathrm{F}$, \%) was -5.91 in group $1,-5.88$ in group $2,-5.82$ in group $3,-6.06$ in group $4(\mathrm{p}\rangle 0.05)$. loss of minerals $\left(\triangle \mathrm{Q}, \%, \mathrm{~mm}^{2}\right)$ was -245.72 in group1, -146.40 in group2, -143.50 in group3, -251.98 in group4(p $>0.05)$. Decalcified area (area, $\left.\mathrm{mm}^{2}\right)$ was 40.75(35.3) in group1, 24.05(48.13) in group2, 23.9(22.02) in group3, 28.28(58.41) in group4(p>0.05). Loss of fluorescence, loss of minerals and decalcified area of group2 and group3 were lower than group1 and 4. But there were no significant difference among groups. Compressive strength(MPa) was 148.99 in group1, 121.12 in group2, 62.59 in group3, 19.38 in group4, decreased statistically significant $(\mathrm{p}<0.05)$. Although there were no significant difference to resistance of decalcification, it was showed that resistance of decalcification of glass ionomer cement containing $5 \%$ and $15 \%$ of $\alpha$-TCP were lower than glass ionomer cement.

Key words: Decalcification, Glass ionomer, $\alpha$-TCP(alpha-tricalcium phosphate), QLF(Quantitative light-induced fluorescence)

\section{INTRODUCTION}

* Correspondence: Myung-Eun Kim

충북 제천시 대학로 316 대원대학교 치위생과

Tel: +82-043-649-3322, Fax: +82-043-649-3693

E-mail: 1010kme@mail.daewon.ac.kr

Received: Apr 03, 2015; Revised: Apr 25, 2015; Accepted: Apr 25, 2015
이차우식증은 수복 후 수복물 주변에 존재하는 우식성 병 변이며(Mjör 등, 2000) 이는 수복재 유형과 상관없이 수복물 을 교체해야 하는 중요한 이유이다(Mjör, 2005).

이차우식증을 억제하는 수복재에 대한 연구로는 불소 이용 (Kim 등, 2010; Hwang 등, 2002), 항균제 첨가(Wu 등, 2012) 및 칼슘 포스페이트를 첨가하는 방법(Xu 등, 2011) 등 많은

* 이 논문은 2014년 신구대학교 교원연구역량강화 연구비 지원에 의해 수행된 것임. 
연구가 이루어져왔으며 이를 통해 구강 내 항세균성과 항우식 성을 증가시키고자 하였다.

수복재 중 글라스 아이오노머 시멘트는 치아와 화학적으로 결합하는 구조적 특징과 인체에 대한 생체친화성을 가지며 특히 불소 방출 등에 의해 세균의 대사를 억제하고 부착을 억제하는 작용을 통해 항우식효과를 나타낸다(Kim 등, 2013; Lee, 2000에서 재인용).

특히 글라스 아이오노머 시멘트에 칼슘포스페이트를 첨가 하면 항우식 특성이 증가된다는 연구가 있다. 글라스 아이오 노머 시멘트에 수산화인회석(HA)을 적정량 첨가하여 탈회저 항성을 측정하였으며(Kim 등, 2013), 나노 크기의 $\beta$-TCP를 첨가하여 항우식과 재광화 효과를 제시한 연구가 있었다 (Hong 등, 2008).

칼슘포스페이트는 인체의 무기질과 유사한 화학적 조성과 특성을 가지고 있고(Ayed 와 Bouaziz, 2008) 칼슘과 인산 이 온을 유리시켜 탈회에 저항하며 법랑질과 상아질 병소를 재광 화시키는 특성을 가지고 있다(Bouslama 등 2010; Seeley 등 2008).

칼슘포스페이트 중 $\alpha$-TCP(alpha-tricalcium phosphate)를 기반으로 한 생체활성 인산칼슘 골 접착제 또한 1980년대 이 후로 각광받아 왔으며 다양한 가수분해가 가능한 골 접착제의 주요 구성성분으로 알려져 있다(Carrodeguas와 De Aza, 2011).

$\alpha-\mathrm{TCP}$ 와 $\beta$-TCP는 같은 화학적 구성을 가짐에도 불구하 고 분자구조, 밀도, 용해도가 달라 각기 다른 임상적 접근이나 생화학적 특징을 가지고 있고 $\alpha$-TCP phase는 실온에서 준안 정된 상태를 유지하고 이온 치환의 영향에서도 안정된 범위를 가진다(Carrodeguas와 De Aza, 2011). 또한 항균성 물질을 포함하고 있는 $\alpha-\mathrm{TCP}$ 를 포함한 시멘트는 우식이 있는 상아 질의 재광화를 향상시킬 수 있는 칼슘 $(\mathrm{Ca})$ 을 방출한다고 하였 다(Akashi 등, 2001).

와동형성 전의 초기 치아우식증에 대한 탈회나 재광화 정 도를 측정하는 방법은 임상적으로 판단하기 어렵고 변화 양상 을 알아내기 쉽지 않다(You와 Kim, 2012).

QLF(Quantitative light-induced fluorescence)는 치아표면 에 녹청색광을 비추면 형광을 발산하는데 법랑질이 탈회된 곳은 발산된 형광의 산란이 증가되어 정상 법랑질이 어둡게
보이는 현상을 이용하여 우식을 감지하는 진단장비로서 초기 우식의 깊이를 예측할 수 있어 병소변화 관찰의 토대가 된다 고 볼 수 있다(You와 Kim, 2012).

이 연구의 목적은 $\alpha$-TCP 함량에 따른 글라스 아이오노머 시멘트 수복물 주변의 탈회저항성을 측정함으로써 $\alpha-\mathrm{TCP}$ 를 함유한 글라스 아이오노머 시멘트의 법랑질 탈회 저항성 효과 를 확인해 보고자하였다.

\section{MATERIALS AND METHODS}

\section{1. 연구재료}

본 실험에서는 수복용 자가중합형 글라스 아이오노머 시멘 트(GC Fuji II, Japan)를 사용하였으며, $\alpha$-TCP(Ossgen, Korea) $0 \%, 5 \%, 15 \%, 25 \%$ 를 글라스 아이오노머 시멘트 분말에 혼합하여 4 개 군의 $\alpha$-TCP 함유 글라스 아이오노머를 제조하였다.

탈회저항성 측정을 위해 소의 전치를 사용하였으며 치아 주변의 이물질을 기계적으로 제거한 후 증류수로 세척하였다.

탈회용액 제조는 $\operatorname{Kim}(2014)$ 의 연구에 따라 진행하였으며 $1.0 \mathrm{M}$ 의 lactic acid와 $2 \%$ 의 carbopol stock solution을 이용 하여 $\mathrm{pH} 4.8$ 의 탈회용액을 제조하였다.

\section{2. 연구방법}

\section{1) 탈회저항성 측정}

(1) 시편 제작

우전치의 치관을 $5 \times 8 \mathrm{~mm}$ 크기의 법랑질 표면을 갖도록 절 제한 후 투명 아크릴 레진 블록(E.Z.O, Korea)에 법랑질이 노출되도록 포매하고 우전치 법랑질 면을 단계적으로 연마하 여 편평하게 하였다. 포매한 우전치에 $4 \times 2 \times 2 \mathrm{~mm}$ 크기의 와 동을 형성하였고 40 개의 시편을 제작하고 10 개씩 4 군으로 무 작위 분류하였다.

와동에 각 군의 글라스 아이오노머 시멘트를 제조사의 지시에 따라 혼합하여 기포 없이 약간 과잉 충전한 후 폴리에스테르필름 (Saehan, Korea)과 슬라이드글라스(Paul Marienfeld GmbH \& Co.KG, Germany)를 올린 후 중합될 때까지 기다렸다. 


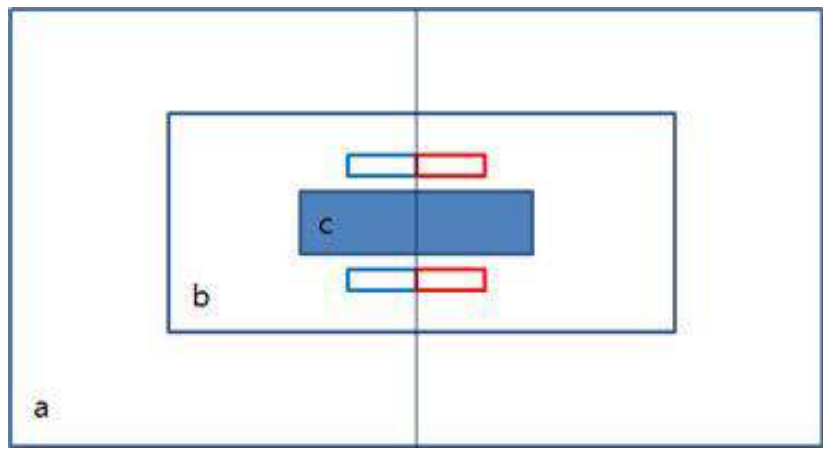

Figure 1. Diagram of specimens for QLF-D measurement. Left half of $b$ is sound and right half of $b$ is demineralization. $a$ : resin block, b: bovine tooth block, c: restorative materials.

충전한 면은 silicon carbide paper \#400, \#1200, \#2000 grit 을 가지고 연마한 후 증류수로 표면을 세척, 건조하였다. 동일 시편에서 탈회정도를 비교할 수 있도록 표면의 절반은 내산성 이 있는 바니쉬로 $2 \sim 3$ 회 얇게 바른 후 건조시켰다. 각 시편은 $10 \mathrm{ml}$ 의 탈회용액이 담긴 개별적인 플라스틱 용기 내에 침적 시켰다. 침적 후 시편은 $37{ }^{\circ} \mathrm{C}$ 에서 96시간 동안 보관하여 탈 회를 시행하였다. 탈회 후 시편을 꺼내어 증류수로 세척, 건조 한 후 아세톤을 이용하여 바니쉬를 제거하였다.

(2) QLF-D 측정

탈회저항성 측정을 위해 QLF-D Biluminator (Biluminator ${ }^{\mathrm{TM}}$ 2 , Inspektor research system BV, Amster dam, Netherlands) 를 사용하였다. 편평한 바닥 위에 시편을 올린 후 QLF 장치를 이용하여 어두운 환경 하에 촬영을 시행하였다. 촬영 후 QLF 전용 프로그램인 QA2 v 1.23 (Inspektor research system BV, Netherlands)을 이용하여 영상을 모니터에 띄운 후 충전면 위 쪽과 아래쪽의 $\Delta \mathrm{F}$ 값과, $\Delta \mathrm{Q}$ 값 그리고 탈회면적을 각각 측정 하여 평균값을 산출하였다. 측정 시에는 측정의 오차를 줄이 기 위해 일정 크기의 격자를 가지고 측정 범위를 설정하였다. $\triangle \mathrm{F}(\%)$ 는 병소부위의 형광소실량(fluorescense)을 나타내는 데 건전한 부위와 비교했을 때 초기우식 병소 부위의 줄어든 형광량을 상대적으로 제시해 주는 변수이고, $\operatorname{Area}\left(\mathrm{mm}^{2}\right)$ 는 법 랑질 최외각 부위에서 측정된 병소의 면적을 나타내는 변수이 며, $\triangle \mathrm{Q}\left(\%, \mathrm{~mm}^{2}\right)$ 는 $\triangle \mathrm{F}$ 와 Area의 곱으로 전체 병소의 부피를 의미한다(김백일과 윤홍철, 2013).

\section{2) 압축강도 측정}

(1) 시편 제작

높이 $(6.0 \pm 0.1) \mathrm{mm}$, 직경 $(4.0 \pm 0.1) \mathrm{mm}$ 의 분할형 몰드를 분리 하여 내면에 바셀린을 바르고 조립하였다. 슬라이드 글라스 위에 아세테이트 필름을 올리고 몰드를 놓았다. 설명서에 따 라 혼합한 시멘트를 기포 없이 몰드에 살짝 넘치도록 채우고 과잉시멘트를 제거한 후 아세테이트 필름을 덮고, 슬라이드 글라스를 올리고 압박을 가하였다. $(37 \pm 1){ }^{\circ} \mathrm{C}, 30 \%$ 상대습 도에 1 시간 보관 후 시편을 제거하였다. 시편의 양쪽 끝을 편평하게 \#400 SiC 연마지로 갈아서 시편의 장축이 직각이 되도록 하였다. 각각 그룹을 ISO 3696 규정에 따라 3차 증류 수에 침적하여 $(37 \pm 1){ }^{\circ} \mathrm{C}$ 에서 24 시간 보관하였다.

(2) 압축강도 측정

4 개의 각 군별 20 개의 시편을 제작하고 시편의 직경을 2 회 (가로, 세로) 측정하여 평균을 구하고, 혼합종료 24시간 후 시편의 물기를 제거하고 만능시험기(Instron 3366, Instron, Norwood, MA, USA)에 시편을 놓고 cross-head speed $1 \mathrm{~mm}$ $/ \mathrm{min}$ 으로 압축강도를 측정하였다. 압축강도 $(\mathrm{MPa})$ 는 ISO 규 격에 제시된 아래의 공식에 따라 구하였다.

$$
C=\frac{4 p}{\pi d^{2}}
$$

$\mathrm{p}$ : 최대 인가 하중 $(\mathrm{N})$

$\mathrm{d}$ : 시편의 직경 $(\mathrm{mm})$

\section{3) 통계처리}

각 그룹 별 $\Delta \mathrm{F}$ 값, $\Delta \mathrm{Q}$ 값, 탈회면적 그리고 압축강도는 평 균과 표준편차를 산출하였고 각 그룹 간의 차이를 알아보기 위해 ANOVA 검정을 시행하였다(유의수준 0.05). 통계프로 그램은 SPSS 패키지 12.0 프로그램을 이용하였다. 
Table 1. Comparison of fluorescence loss

\begin{tabular}{cccccc}
\hline & Group 1 & Group 2 & Group 3 & Group 4 & $\begin{array}{c}\text { p-value } \\
\text { (Group 1,2,3) }\end{array}$ \\
\hline$\triangle F(\%)$ & -5.91 & -5.88 & -5.82 & -6.06 & 0.565 \\
SD & 0.35 & 0.48 & 0.37 & 0.35 & $(0.874)$ \\
\hline
\end{tabular}
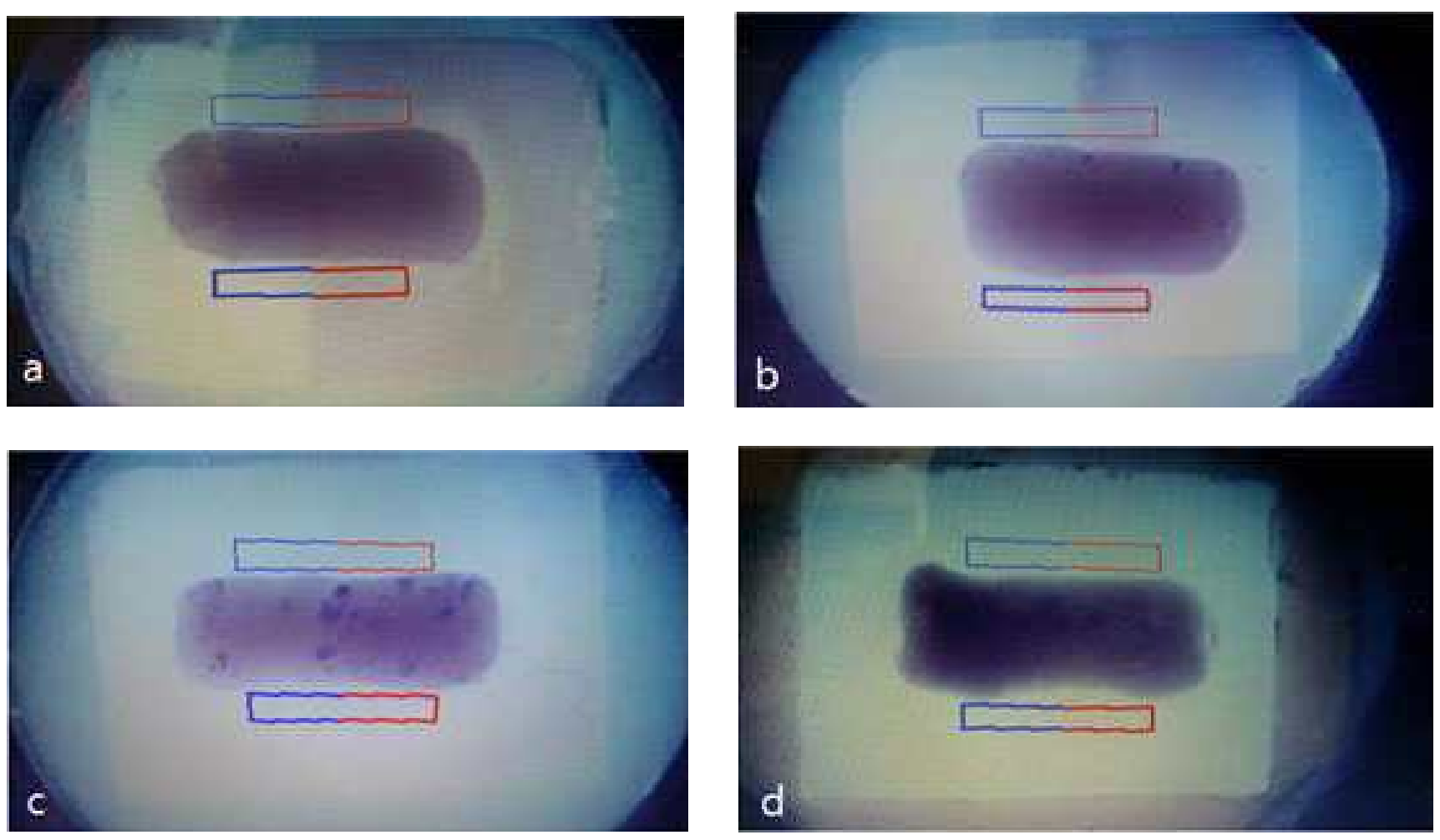

Figure 2. QLF image of each groups after demineralization for 96 hours. Left(blue box) was not demineralized and right(red box) was demineralized in each image(Mass of $\alpha$-TCP a: $0 \%$, b: $5 \%$, c: $15 \%$, d: $25 \%$ ).

\section{RESULTS}

\section{1. 형광 소실량 비교}

형광 소실량 $(\triangle \mathrm{F}, \%)$ 을 비교한 결과 1군에서 $-5.91 \pm 0.35$, 2 군에서 $-5.88 \pm 0.48,3$ 군에서 $-5.82 \pm 0.37$, 4 군에서 $-6.06 \pm 0.35$ 을 나타냈다. 3 군까지 $\alpha-\mathrm{TCP}$ 의 함량이 많을수록 점차 형광 소실량이 감소하였으나, 4 군에서는 다시 형광소실량이 증가 하는 양상을 보여 유의한 차이가 없었다(p>0.05)(Table 1).

\section{2. 무기질 소실량 비교}

무기질 소실량 $\left(\triangle \mathrm{Q}, \%, \mathrm{~mm}^{2}\right)$ 을 비교해 본 결과 1 군에서 $-245.72 \pm 237.05,2$ 군에서 $-146.40 \pm 306.38,3$ 군에서 -143.50 $\pm 138.05,4$ 군에서 $-251.98 \pm 316.46$ 을 나타냈다. 3군까지 $\alpha-\mathrm{TCP}$ 의 함량이 많을수록 점차 무기질 소실량이 감소하였으 나, 4 군에서는 무기질 소실량이 증가하는 양상을 보여 유의한 차이가 없었다(p>0.05)(Table 2). 
Table 2. Comparison of demineralization

\begin{tabular}{|c|c|c|c|c|c|}
\hline & Group 1 & Group 2 & Group 3 & Group 4 & $\begin{array}{c}\text { p-value } \\
\text { (Group 1,2,3) }\end{array}$ \\
\hline$\triangle \mathrm{Q}\left(\%, \mathrm{~mm}^{2}\right)$ & -245.72 & -146.40 & -143.50 & -251.98 & \multirow{2}{*}{$\begin{array}{c}0.666 \\
(0.556)\end{array}$} \\
\hline SD & 237.05 & 306.38 & 138.05 & 316.46 & \\
\hline
\end{tabular}

Table 3. Comparison of decalcified area

\begin{tabular}{cccccc}
\hline & Group 1 & Group 2 & Group 3 & Group 4 & $\begin{array}{c}\text { p-value } \\
\text { (Group 1,2,3) }\end{array}$ \\
\cline { 1 - 4 } $\begin{array}{c}\text { Decalcified } \\
\text { area(mm2) }\end{array}$ & 40.75 & 24.05 & 23.90 & 28.28 & 0.793 \\
\cline { 2 - 2 } & 35.30 & 48.13 & 22.02 & 58.41 & $(0.508)$ \\
\hline
\end{tabular}

\section{3. 탈회면적 비교}

탈회면적 $\left(\mathrm{mm}^{2}\right)$ 을 비교해 본 결과 1군에서 $40.75 \pm 35.3,2$ 군

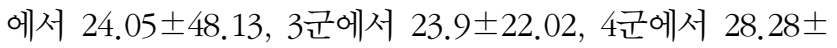
58.41 을 나타냈다. 탈회면적 역시 형광 소실량 및 무기질 소 실량과 마찬가지로 3군까지 $\alpha-\mathrm{TCP}$ 의 함량이 많을수록 점차 탈회면적이 감소된 양상을 보였으나 4군에서는 탈회면적이 다소 높아지는 양상을 보여 유의한 차이가 없었다 $(\mathrm{p}>0.05)$ (Table 3).

\section{Compressive strength(MPa)}

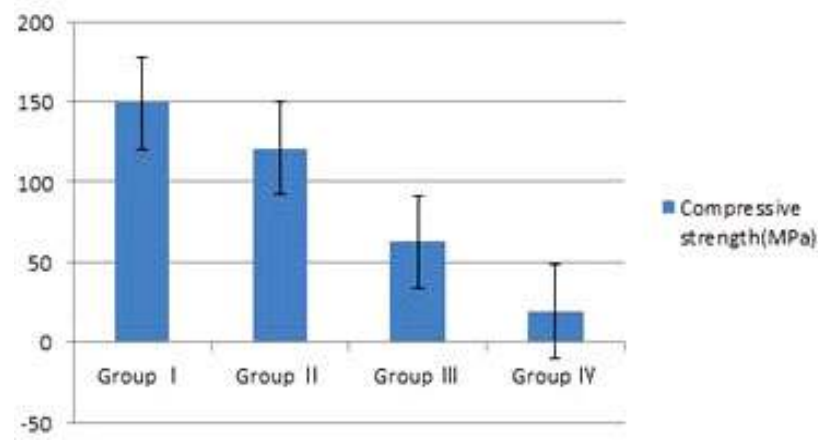

Figure 3. Compressive strength for each group ( $\mathrm{p}$-value $=0.000$ ) .

\section{4. 압축강도 비교}

압축강도(Mpa)를 비교해본 결과 1군에서 148.99(37.63), 2군에서 121.12(21.83), 3군에서 62.59(22.82), 4군에서 $19.38(7.74)$ 을 나타냈다. $\alpha$-TCP의 함량이 많을수록 압축강 도가 유의하게 작아졌다 $(\mathrm{p}<0.05)$ (Figure 3).

\section{DISCUSSION}

글라스 아이오노머 시멘트는 다량의 불소를 함유하고 있을 뿐 아니라 이온결합에 의해 치질과 직접 접착되고 치아와 유 사한 열팽창계수 및 색조를 가지고 있으며 유리된 불소에 의 해 인접 법랑질의 항우식 효과를 가진다.(Deschepper 등, 1991; Hotta와 Aono, 1994; Forsten, 1995; Pereira 등, 1998; Grobler 등, 1998).

그러나 물성과 치질과의 결합력, 심미성 등이 떨어지고 수 분에 민감하여 조작이 불편한 단점을 가지고 있다(Hwang 등, 2002에서 재인용)

글라스 아이오노머 시멘트의 장점을 극대화하고 낮은 물리 적 성질을 보완하기 위해 글라스 아이오노머 시멘트에 다양한 
재료를 첨가하는 연구가 이루어졌는데 그 중 칼슘포스페이트 제제는 생체친화성이 뛰어나고 법랑질 재광화를 촉진시킨다 (Kumar 등, 2008; Cochrane 등, 2010)

칼슘포스페이트 제제의 법랑질 재광화 효과는 칼슘포스페 이트 결정이 광물질의 저장고로 작용하여 법랑질 면에 무기이 온을 공급하고 탈회된 곳에 수산화인회석 포화도를 증가시키 는 데에 기인한다(Reynolds, 1998).

칼슘포스페이트는 칼슘과 인의 비율에 의해 구분되는데 $\mathrm{Ca}_{3}\left(\mathrm{PO}_{4}\right)_{2} \cdot \mathrm{HH}_{2} \mathrm{O}$ 의 화학적 구성을 갖는 트리칼슘포스페이트 는 칼슘과 인의 비율이 1.5 이며 형성 온도에 따라 3 가지 형태 를 갖는다(Tabrizi와 Fahami, 2013). 저온에서 형성되는 $\beta$ -TCP, 고온에서 형성되는 $\alpha$-TCP와 초고온에서 형성되는 $\alpha^{\prime}$-TCP가 있으며(M. Descamps 등, 2007) $\alpha$-TCP는 수산화 인회석에 비해 용해도가 높고 반응성이 높으며 일반적으로 분말의 형태로 공급된다(Li Yubao 등, 1997).

법랑질의 탈회정도를 평가하기 위한 방법 중 QLF 시스템은 1 2분 내에 완료할 수 있으며 각 표본 당 측정 소요시간이 약 15 초 이내로 매우 짧은 이점이 있으며 재현성과 신뢰도가 높아 초기 법랑질 우식증 연구 발전에 큰 도움을 주고 있다 (Lee 등, 2004).

QLF는 치아에 청색광의 산란을 이용해 카메라 영상을 획득 하는데 탈회된 법랑질은 형광의 감소가 발생하고 치아에서 형광을 발생시키는 정도와 석회화 수준 간의 상관관계가 있으 며, 자체 소프트웨어를 이용하여 형광 부위의 차이를 탈회의 정도로 정량화한다(Pretty 등, 2003: Karlsson 등, 2007: Adeyemi 등, 2010).

본 실험에서 QLF를 통해 확인한 형광량 및 무기질 소실량, 탈회면적은 3 군 $(15 \%)$ 까지 $\alpha-\mathrm{TCP}$ 의 함량이 많을수록 다소 감소되는 양상을 보였는데 이는 $\alpha-\mathrm{TCP}$ 의 인회석 물질로부터 유리된 칼슘, 인 등의 무기이온이 탈회된 법랑질의 재광화를 촉진시키고 (Domingo 등, 2001; Mazzaoui 등, 2003: Cochrane 등, 2010) 유리된 인회석 입자가 탈회된 법랑질의 미세공극을 메움으로써 법랑질 표면으로부터 용출되는 칼슘, 인산염 등이 이온의 이동을 막을 수 있기 때문으로 생각할 수 있다(Kim 등, 2006). 칼슘, 인산염이 용해되면 구강 내에서 무정형 인산 칼슘(Amorphous calcium phosphate)을 형성하며, 불소가 유 리되고 있는 상태에는 무정형 불화인산칼슘(Amorphous calcium fluoride phosphate)을 형성한다고 하였으며 이것들 은 불안정하여 더 안정된 수산화인회석이나 불화수산화인회 석과 같은 결정을 형성한다고 하였다(Cochrane 등, 2010).

그러나, 본 실험에서 $\alpha$-TCP가 $25 \%$ 포함된 4군은 형광 소실량 및 무기질 소실량이 $\alpha-\mathrm{TCP}$ 가 포함되지 않은 1군보다 증가하였고, 탈회면적도 1 군보다는 감소하였으나 2,3 군 보다 는 증가하는 양상을 보였다.

이것은 $\alpha$-TCP의 총량이 증가하였으므로 칼슘, 인산염의 무기이온의 양은 증가하였으나 글라스 아이오노머 시멘트의 양이 감소함에 따라 불소의 양이 감소하였기 때문이라고 유추 해 볼 수 있다.

이는 칼슘과 인산염이 다량 존재할 경우 반응부산물인 인 산칼슘이온과 수산화인회석, 인산염 자체가 재광화 비율을 낮춘다는 이전 연구결과(Reynolds, 1998)와 유사한 것으로 $\alpha$-TCP가 $25 \%$ 포함된 4군의 탈회면적 감소결과를 설명해 줄 수 있으며 적정량의 칼슘, 인산염, 불소가 존재하는 것이 중요하다는 것을 알 수 있다(Cochrane 등, 2010).

글라스 아이오노머에 칼슘포스페이트를 첨가하여 시멘트 의 물리적 성질을 측정한 Hong의 연구에서 칼슘포스페이트 를 첨가한 글라스 아이오노머의 압축강도가 증가한 것을 확인 하였는데, 이러한 결과는 유리된 칼슘이온이 폴리아크릴릭 용 액과 작용해서 폴리아크릴레이트 이온을 형성하여 강한 이온 결합을 하기 때문이라고 하였다. 그러나 아파타이트의 용해 도가 낮기 때문에 압축강도의 증가는 제한적이라고 보고하였 다(Hong 등, 2008). 그러나 칼슘포스페이트를 첨가한 심미수 복재를 연구한 대부분의 연구에서는 강도가 저하되는 것으로 나타났으며(Mah, 2009, Xu 등, 2011) 이는 크기가 작고 용해 도가 큰 나노 입자들이 크기가 큰 아이오노머 매트릭스 내로 들어가 packing effect가 커지고 과도하게 packing된 입자들 로 인해 오히려 글라스 아이오노머 입자의 교차결합을 방해하 는 작용을 초래할 수 있다고 하였다(Mah, 2009에서 재인용).

본 연구에서 $\alpha-\mathrm{TCP}$ 의 함량이 많을수록 압축강도가 유의하 게 감소하는 결과를 나타냈다. 이는 앞선 Hong 등의 연구와 는 다르고, Mah의 결과와는 유사하다. 국제표준기구(ISO)에 서 글라스 아이오노머 시멘트의 압축강도는 수복용인 경우 $100 \mathrm{MPa}$ 이상, 접착용인 경우 $50 \mathrm{MPa}$ 이상으로 규정하고 있다(ISO 9917-1, 2007). 본 연구에 사용한 것은 수복용이므 
로 $5 \%$ 의 $\alpha$-TCP를 함유한 그룹(121.12 MPa)은 국제표준기 구의 압축강도 기준을 충족하였으나 $\alpha-\mathrm{TCP}$ 를 포함하지 않은 것 보다 압축강도가 감소하였고, 형광 소실량과 무기질 소실 량, 탈회면적 감소에서도 각 군별 통계적으로 유의한 차이가 없었으며, 약간의 감소현상을 보인 $1,2,3$ 군 간에도 통계적으 로 유의한 차이가 없었으므로 처음에 설계했던 $\alpha$-TCP의 법 랑질 탈회저항성 효과를 확인할 수 없었다.

따라서 향후 압축강도를 보강하면서 칼슘포스페이트의 법 랑질 재광화 효과와 불소의 법랑질 항우식 효과를 극대화시킬 수 있는 비율을 찾기 위해 성분 비율을 섬세하게 구분하여 시편의 수를 증가시키고 시간 경과에 따른 재광화 효과를 관 찰할 수 있는 후속연구가 필요할 것으로 사료된다.

\section{CONCLUSION}

수복용 자가중합형 글라스 아이오노머 시멘트에 $\alpha$-TCP를 $0 \%, 5 \%, 15 \%, 25 \%$ 를 포함하여 혼합한 시멘트의 탈회저항 성과 압축강도를 측정한 결과 다음과 같은 결과를 얻었다.

1. 형광 소실량 $(\triangle \mathrm{F}, \%)$ 은 1 군에서 $-5.91 \pm 0.35,2$ 군에서 $-5.88 \pm 0.48,3$ 군에서 $-5.82 \pm 0.37,4$ 군에서 -6.06 \pm 0.35 이었으며 유의한 차이가 없었다 $(\mathrm{p}>0.05)$.

2. 무기질 소실량 $\left(\triangle \mathrm{Q}, \%, \mathrm{~mm}^{2}\right)$ 은 1 군에서 $-245.72 \pm 237.05$, 2군에서 $-146.40 \pm 306.38$, 3군에서 $-143.50 \pm 138.05$, 4 군에서 $-251.98 \pm 316.46$ 이었으며 유의한 차이가 없었 다(p>0.05).

3. 탈회면적 $\left(\mathrm{area}, \mathrm{mm}^{2}\right)$ 은 1 군에서 $40.75 \pm 35.3,2$ 군에서 $24.05 \pm 48.13,3$ 군에서 $23.9 \pm 22.02,4$ 군에서 28.28 \pm 58.41 이었으며 유의한 차이가 없었다( $\mathrm{p}>0.05)$.

4. 압축강도 $(\mathrm{MPa})$ 는 1 군에서 $148.99 \pm 37.63,2$ 군에서 $121.12 \pm 21.83$, 3군에서 $62.59 \pm 22.82$, 4군에서 19.38 \pm 7.74 이었으며, $\alpha-\mathrm{TCP}$ 의 함량이 많을수록 압축강도 가 유의하게 감소되었다 $(\mathrm{p}<0.05)$.

위의 결과를 종합해 볼 때 $\alpha$-TCP 함량에 따라 형광소실량,
무기질 소실량, 탈회면적에 차이가 없었으며, 압축강도는 $\alpha-\mathrm{TCP}$ 의 함량이 증가함에 따라 감소하였으므로 처음에 설계 했던 $\alpha$-TCP의 법랑질 탈회저항성을 확인할 수 없었다.

\section{REFERENCES}

1. 김백일, 윤홍철 (2013). Q-Ray ${ }^{\mathrm{TM}}$ 시스템을 통한 분석 및 진단. Denfoline 143:36

2. Akashi, Y. Matsuya, M. Unemori, A. Akamine (2001). Release profile of antimicrobial agents from $\alpha$-Tricalcium phosphate cement. Biomaterialia 22:2713-2717.

3. Adeyemi AA, Jarad FD, Jong EJ (2010). The evaluation of a novel method comparing quantitative light-induced fluorescenec(QLF) with spectrophotometry to assess staining and bleaching of teeth. Clin Oral Invest 14:19-25.

4. Ayed FB, Bouaziz J (2008). Sintering of tricalcium phosphat-fluorapatite composite by addition of alumina. Ceramics Int 34:1885-1892.

5. Cochrane N, Cai F, Huq N, Burrow M, Reynolds E (2010). New approaches to enhanced remineralization of tooth enamel. $J$ Dent Res 89:1187-1197.

6. Deschepper EJ, Berry EA, Cailleteau JG, Tate WH (1991). A comparative study of fluoride relese from glass ionomer. Quint Int 22:215-220.

7. Domingo C, Arcis R, Lppez-Macipe A, Osorio R, Rodriguez-Clemente R, Murtra J, Fanovich M, Toledano M (2001). Dental composites reinforced with hydroxyapatite : mechanical behavior and absorption/ elution characteristics. J Biomed Mater Res 56:297-305.

8. Forsten L (1995). Resin-modified glass ionomer cements: fluoride relese and uptake. Acta Odontol Scand 53:222-225.

9. Grobler SR, Rossouw RJ, VanWykKotze TJ (1998). A comparison of fluoride release from various dental materials. J Dent 26:259-265. 
10. Hong YW, Kim JH, Lee BH, Lee YK, Choi BJ, Lee JH, Choi HJ (2008). The effect of nano-sized $\beta$-Tricalcium phosphate on remineralization in glass ionomer dental luting cement. Key Eng Mater 361-363:861-864.

11. Hwang GS, Kim JS, Kwon SW (2002). Comparative study on fluoride release and anticariogenic eccect of compomers. J Korean Acad Pediatr Dent 29;1-10. ISO 9917-1 (2007).

12. Karlsson L, Lindgren LE, Trollsas K (2007). Effect of supplementary amine fluoride gel in caries-active adolescents: A clinical QLF study. Acta Odontol Scand 65:284-291.

13. Kim NH, Kim SO, Song JS, Lee JH, Son HK, Choi BJ, Choi HJ (2013). The optimum addition ratio of nano hydroxyapatite to glass ionomer dental cement (Changes in demineralization resistance and bonding strength of light cured glass ionomer after the addition of nano hydroxyapatite in various ratio). J Korean Acad Pediatr Dent 40:159-167.

14. Kim ME (2014). Resistance to incipient caries and properties of composite resin containing nano-sized tricalcium phosphate fluorapatite (TCP-FA) filler. Doctorial thesis, Yonsei Univeristy, Seoul.

15. Kim MY, Kwon HK, Kim BI (2006). The comparison of remineralizing effect on mouthrinse containing nano sized or micro sized hydroxyapatite. $J$ Korean Acad Dent Health 30:325-334.

16. Kim SY, Choi SC, Kim KC, Choi YC, Park JH (2010). In vitro study of demineralization inhibition effect and fluoride uptake into adjacent teeth of light-cured fluordie-releasing restoratives. Korean Acad Pediatr Dent 37:288-297.

17. Kumar V, Itthagarun A, King N (2008). The effect of casein phosphopeptide amorphous calcium phosphate on remineralization of artificial caries like lesions: an in vitro study. Aust Dent J 53:34-40.

18. Lee Ck, Kim JS, Yoo SH (2004). Comparative study on the rate of dental enamel demineralization using a QLF. J Korean Acad Pediatr Dent 31:506-515.

19. Lee $\mathrm{JM}(2000)$. A study of fluoride release and physical property in fluoride-conatining esthetic restorative materials. Master's thesis. Yonsei University, Seoul.

20. Li Yubao, Zhang Xingdong and K. de Groot (1997). Hydrolysis and phase transition of alpha-tricalcium phosphate. Biomaterials 18:737-741.

21. Mah YJ (2009). The resistance of demineralization and bonding strength of light cured glass ionomer dental cement filled with nano-sized hydorxyapatite and beta-tricalcium phosphate. Master;s thesis Yonsei University, Seoul.

22. Mazzaoui S, Burrow M, Tyas M, Dashper S, Eakins D, Reynolds E (2003). Incorporation of casein phosphopeptide-amorphous calcium phosphate in to glass ionomer cement. J Dent Res 82:914-918.

23. M. Descamps, J.C. Hornez, A. Leriche (2007). Effects of powder stoichiometry on the sintering of $\beta$ -tricalcium phosphate. J Eur Ceram SOC 27:2401-2406.

24. Mjör IA, Moorhead JE, Dahl JE (2000). Reason for replacement of restoration in permanent teeth in general dental practice. Int Dent J 50:360-366.

25. Mjör IA. Clinical diagnosis of recurrent caries(2005). J Am Dent Assoc 136:1426-1433.

26. Pereira PN, Yamada T, Inohoshi S, Burrow MF (1998). Adhesion of resin-modified glass ionomer cements using resin bonding system. $J$ Dent 26:479-485.

27. Pretty IA, Pender N, Edger WM, Higham SM (2003). The in vitro detection of early enamel de-and re-mineralization adjacent to bonded orthodontic cleats using quantitative light-induced fluorescence. Eur $J$ Orthod 25:217-223.

28. Reynolds E (1998). Anticariogenic complexes of amorphous calcium phosphate stabilized by casein phosphopeptides: a review. Spec Care Dentist 18:8-16. 29. R.G. Carrodeguas, S. De Aza (2011). $\alpha$-Tricalcium 
phosphate: synthesis, properyies and biomedical applications. Acta Biomaterialia 7:3536-3546.

30. Tabrizi BN, Fahami A (2013). Mechanochemical synthesis and structural characterization of nano-sized amorphous tricalcium phosphate. Ceramics In 39: 8657-8666.

31. Wu J, Jin C, Nie Z, Zhou K, Zhou C (2012). Study on synthesis on a novel nano-antibacterial inorganic filler and its antibacterial property. West China J Stomatol
30:526-529.

32. You YS, Kim JS (2012). Monitoring of remineralization of decalcified enamel using quantitative light-induced fluorescence-D. J Korean Acad Pediatr Dent 39:257-266.

33. Xu HHK, Moreau JL, Sun L, Chow LC (2011). Nanocomposite containing amporhous calcium phosphate nanoparticles for caries inhibition. Dent Mater 27:762-769. 